\title{
Synovial sarcoma. Evaluation of prognosis with emphasis on the study of DNA ploidy and proliferation (PCNA and $\mathrm{Ki}-67$ ) markers
}

\author{
José M. Lopes $^{\mathrm{a}, *}$, Einar Hannisdal ${ }^{\mathrm{b}}$, Bodil Bjerkehagen ${ }^{\mathrm{c}}, \varnothing_{\text {yvind S. Bruland }}^{\mathrm{b}}$, \\ Håvard E. Danielsen ${ }^{\mathrm{b}}$, Erik O. Pettersen ${ }^{\mathrm{d}}$, Manuel Sobrinho-Simões ${ }^{\mathrm{a}}$ and Jahn M. Nesland ${ }^{\mathrm{c}}$ \\ ${ }^{\mathrm{a}}$ Unit of Molecular Pathology, IPATIMUP, Medical Faculty, Porto, Portugal \\ ${ }^{\mathrm{b}}$ Departments of Medical Oncology and Radiotherapy, ${ }^{\mathrm{c}}$ Pathology and ${ }^{\mathrm{d}}$ Tissue Culture, \\ The Norwegian Radium Hospital and Institute for Cancer Research, Montebello, Oslo, Norway
}

Received 17 September 1996

Revised 23 October 1997

Accepted 2 January 1998

\begin{abstract}
Controversy still exists regarding the validity of parameters commonly used in the evaluation of prognosis of patients with synovial sarcoma (SS). Forty-nine cases of previously untreated primary SS (23 females and 26 males, ranging in age from 7 to 81 , with 31 tumors located in the lower extremity, 8 at the upper extremity and 10 at the trunchus), without regional lymph-node or distant metastases were studied. We investigated the relationship between (flow and image) DNA cytometry, proliferation activity, clinicopathologic parameters, and relapse-free and overall survival of the patients. The prognostic value of gender, age, duration of symptoms, location, compartmentalization, size, adequacy of surgical margins, residual tumor, adjuvant therapy, histologic subtype, extent of necrosis, glandular differentiation, calcification, and extent of hemangiopericytic areas, mitotic rate, amount of mast cells, blood vessel invasion, histologic (UICC and NCI) grades, DNA ploidy, percentage of cells in S and S+G2 phases, PCNA and Ki-67 labeling indices (LI), and TNM (UICC) stage of the tumors, were evaluated by univariate and multivariate (Cox hazard model) analyses. Short duration of symptoms $(<12$ months), biphasic SS, scarcity of mast cells $(<10 / 10 \mathrm{HPF})$, high mitotic rate $(\geqslant 10 / 10 \mathrm{HPF})$, high histologic grade (grade 3), high PCNA-LI $(\geqslant 20 \%)$, high Ki-67-LI $(\geqslant 10 \%)$, DNA aneuploidy, and advanced TNM stage (stage III) were features associated with significantly shorter relapse-free and overall 5-year survival rates in the univariate analyses. Scarcity of mast cells, high mitotic rate, or high PCNA-LI were significant predictors of poor survival, in addition to TNM stage in the multivariate analyses. The amount of mast cells was inversely correlated with mitotic rate and PCNA-LI. Scarcity of mast cells, high mitotic rate, or high PCNA-LI are factors associated with poor prognosis, in addition to advanced TNM stage in patients with localized SS.
\end{abstract}

Keywords: Synovial sarcoma, mast cells, mitotic rate, PCNA, staging, prognosis, Ki-67, DNA flow cytometry, DNA image cytometry, soft tissue tumor

\footnotetext{
*Adress for correspondence: Department of Pathology, IPATIMUP, Medical School of Porto, Hospital S. João, 4200 Porto, Portugal. Fax: 35125570799.
}

0921-8912/98/\$8.00 @ 1998 - IOS Press. All rights reserved 


\section{Introduction}

Many clinical and morphological features have been applied to the evaluation of the prognosis of synovial sarcoma (SS), such as gender, age at diagnosis, clinical symptoms, location of tumor, staging of the neoplastic disease, treatment modalities, tumor size, histologic subtype, extent of glandular differentiation, mitotic rate, histologic grading, presence of rhabdoid cells, amount of mast cells, extent of calcification, DNA ploidy score, and PCNA score. However, there is still contradictory and insufficient evidence concerning the validity of most of these parameters $[2,6,8,10,17,19,20,22,23,25$, $29,33,34,36-39,41,43,44,47,50,52,56]$.

It is well established that staging is the most important parameter in the evaluation of soft tissue sarcomas. It gives valuable information, guiding both choice of treatment and prognosis. Tumor size, local spread, metastases, and histologic grade have all been used in different staging systems of soft tissue sarcomas $[18,19,28]$.

The prognostic significance of histologic subtyping of SS remains controversial. Several authors conclude that there are no significant differences between the survival of patients with the two most common subtypes of SS (BSS and MSS) [6,10,17,22,23,25,33,38,39,43]. On the other hand, some groups have found BSS to carry a more favorable prognosis $[8,56]$ and others have found that MSS appears to be the less aggressive variant $[36,47]$.

The prognostic values of DNA cytometry parameters (DNA ploidy and percentage of tumor cells in $\mathrm{S}$ and $\mathrm{S}+\mathrm{G} 2$ phases) have been studied in several series of different histologic types of soft tissue sarcomas $[2,17,19,38,53]$.

In this study, we have performed a retrospective evaluation regarding the influence on the survival of 49 patients with primary SS of various clinicopathologic features, with particular emphasis on the analysis of DNA cytometric and proliferative parameters.

\section{Patients and methods}

Forty-nine near-consecutive cases of primary synovial sarcoma (SS) treated by surgery were selected from the files of the Department of Pathology, The Norwegian Radium Hospital (36 cases from 1981 to 1991) and Porto Medical School (13 cases from 1967 to 1991). The only criterion for exclusion was the presence of regional lymph-node metastases or distant metastases. Preoperative radiotherapy was not given to any patient.

\subsection{Clinical features}

Clinical data were collected from the patients' medical records. The surgical margins were classified according to the criteria of Enneking et al. [18]. Margins obtained at the second operation were recorded, whenever the primary tumors were treated by two sequential surgical procedures separated by less than one month, in an attempt to achieve adequate surgical margins.

Follow-up was done by clinical examination every third month for the first year, with subsequently longer intervals for the following years. Chest X-rays and blood profile, including liver function tests, were performed at each visit. CT-scans of the lung were performed whenever chest X-rays indicated metastases or were inconclusive. 


\subsection{Pathologic features}

All available material for histologic study was examined without knowledge of the clinical course of the patients, using formalin-fixed paraffin-embedded $5 \mu \mathrm{m}$ sections (4-15 per tumor) stained with hematoxylin and eosin. Representative sections from the surgical margins of each tumor were also histologically evaluated.

The cases were classified, according to the criteria of Enzinger and Weiss [19], in biphasic (BSS, $n=19$ ) and monophasic (MSS, $n=30$ ) subtypes of SS. Whenever necessary, immunohistochemical and ultrastructural examinations were performed to confirm the diagnosis.

In 42 cases, formalin-fixed paraffin-embedded fragments were available for the following analyses performed in consecutive sections of one representative block from each tumor: DNA flow cytometry (FCM) in 42 cases, DNA image cytometry (ICM) in 41 cases, PCNA immunohistochemistry and acidified toluidine blue (pH 3.0) in 40 cases, and Ki-67 in 37 cases, depending on the representation of tumor tissue available in each section of the paraffin blocks that had been selected.

Mitotic rate was determined by counting the most mitotic areas in 10 successive high power fields (HPF; $\times 400$ measured $0.15 \mathrm{~mm}^{2}$ ) selected at random. The amount of mast cells was evaluated in 10 successive HPF cells chosen at random after selecting the area displaying the highest number of mast cells. The percentage of extent of tumor necrosis (based on gross and microscopical findings), as well as that of solid/glandular areas, were evaluated in all the sections and classified as follows: $0 ;<15 ; 15-50 ;>50$. Extent of calcification and extent of hemangiopericytic areas were classified in four degrees: 0 (none); $+(<15 \%) ;++(15-30 \%) ;+++(>30 \%)$. Histologic grade of malignancy was independently evaluated according to UICC [28] and NCI [13] grading systems. Briefly, UICC grade (1-3) was based on the estimation of cellularity, cellular pleomorphism (e.g., nuclear atypia), mitotic activity, and necrosis. NCI grading was based on the gross and microscopical evaluation of necrosis: $<15 \%=$ grade $2,>15 \%=$ grade 3 . Blood vessel invasion was classified as absent or present. Residual tumor at the surgical margins (R0, no residual tumor; R1, microscopical residual tumor; R2, macroscopical residual tumor) and TNM staging (I to III) of the tumors were classified according to the UICC system [28].

\subsection{Immunohistochemistry}

Formalin-fixed paraffin-embedded sections were stained using the avidin-biotin peroxidase complex (ABC) method [27]. Deparaffinized sections were treated with $0.3 \%$ hydrogen peroxide $\left(\mathrm{H}_{2} \mathrm{O}_{2}\right)$ in methanol for 30 min to block endogenous peroxidase. To unmask the epitopes of PCNA and Ki-67 the sections were microwaved in $<1 \%$ lead solution [45] and $10 \mathrm{mM}$ citrate buffer $\mathrm{pH} 6.0$ [11]. The sections were then incubated for 20 min with normal serum from the species in which the secondary antibody was made. This was done to minimize nonspecific staining. Excess normal serum was blotted from slides before incubation with monoclonal PCNA antibody diluted 1:25 (NCL-PCNA, Novocastra Laboratory, UK) and polyclonal Ki-67, antibody diluted 1:100 (A 047, Dako, Denmark) for 18-22 h at $4{ }^{\circ} \mathrm{C}$. The sections were then incubated with $1: 200$ dilution of biotin-labeled secondary antibody for $30 \mathrm{~min}$ and $\mathrm{ABC}(10 \mu \mathrm{g} / \mathrm{ml}$ of avidin and $2.4 \mu \mathrm{g} / \mathrm{ml}$ of biotin-labeled peroxidase) for $60 \mathrm{~min}$ (Vector, Burlingame, CA, USA). The tissue sections were stained for 5 min with $0.05 \%$ 3',3-diaminobenzidine tetrahydrochloride (DAB) freshly prepared in $0.05 \mathrm{M}$ tris(hydroxymethyl) aminomethane (Tris) buffer at $\mathrm{pH}$ 7.6, containing $0.01 \% \mathrm{H}_{2} \mathrm{O}_{2}$ and then counterstained with hematoxylin, dehydrate, and mounted in Diatex. All dilutions of normal sera, antiserum, biotin-labeled secondary antibodies and ABC were made with PBS containing 5\% bovine serum albumin. All series included positive controls. Negative 
controls included substitution of polyclonal antibody with normal rabbit IgG, whereas negative control for the monoclonal antibody was performed using mouse myeloma protein of the same subclass and concentration. All control examinations were satisfactory.

Immunoreaction for PCNA and Ki-67 was considered positive whenever nuclear staining was observed, independently of the intensity of the staining. Areas with more numerously stained nuclei were selected and used for counting at random. The labeling indices were determined in every case by counting the number of positive tumor cell nuclei among a total of 1000 cells. The labeling indices were expressed in percentage of positive cells.

\subsection{DNA cytometry}

To minimize the amount of non-tumor tissue, all areas with tumor were outlined on blocks corresponding to the best sections, and most of the non-tumor tissue was removed. From each block one $100-\mu \mathrm{m}$ section for DNA flow cytometry (FCM) and two 50- $\mu \mathrm{m}$ sections for DNA image cytometry (ICM) were cut. In the end, a 5- $\mu \mathrm{m}$ section was cut for evaluation of representativity of the section and for the estimation of the amount of tumor tissue present. After deparaffinization with xylol, the tissues were rehydrated in graded ethanols, rinsed in phosphate-buffered saline (PBS) and incubated for $30 \mathrm{~min}$ with protease (Sigma no. 24) at $37^{\circ} \mathrm{C}$. The protease activity was stopped by adding $4 \mathrm{ml}$ cold PBS, and thereafter the specimens were rinsed twice in $4 \mathrm{ml}$ PBS before centrifugation at $1250 \times \mathrm{g}$ [24]. The specimens were prepared in series to control interspecimen variation of the disintegration index.

\subsection{Flow cytometry}

Cell suspensions were prepared by the method described by Hedley [24], with minor modifications [21], stained with ethidium bromide. DNA FCM was performed by the use of a laboratory-built flow cytometer [35]. Briefly, the instrument was based on a Nikon Diaphot invertoscope equipped with excitation light ranges of $510-560 \mathrm{~nm}$ and a beam splitter at $580 \mathrm{~nm}$. The output signals were sorted by a multichannel analyzer (Nuclear Data ND 66) into histograms with 256 channels.

\subsection{Image cytometry}

The isolated cells were post-fixed in buffered $4 \%$ formalin for at least $12 \mathrm{~h}$ in room temperature and centrifuged (Hettich, Tuttingen, Germany) on polylysin-coated slides at $1250 \times \mathrm{g}$. Feulgen Schiff staining was applied $\left(5 \mathrm{~N} \mathrm{HCl}, 60 \mathrm{~min}, 22^{\circ} \mathrm{C}\right)$ with Pararosanilin-Schiff. Hydrolysis curves were made to ensure reproducible staining. Images of the nuclei obtained with a Zeiss photomicroscope III equipped with a plan 40/0.95 objective lens and a 546-nm green filter were transferred to a MINI-IPS image processing unit (Kontron, Munich, Germany) using a Grundig FA 76 camera with a pasecon tube with a fixed gain level. The image processing unit was equipped with 4 megabytes of image memory, array processor and digitizer unit controlled by a Z80 host processor. Images were stored as $512 \times 512$ pixels with 256 gray levels. The software was written in FORTRAN using Kontron's subroutine library for access to the array processor. The integrated optical density of each nucleus was calculated on the basis of measurements of optical density and area. Background optical density was measured and corrected for each image, ensuring stable and reproducible measurements.

At least 300 nuclei per specimen were measured. Normal human lymphocytes were used as external staining controls of the normal diploid (2c) DNA content due to the scarcity of lymphoid cells 
observed in SS. All nuclei were randomly selected from multiple areas of the slide. Only nuclei which were structurally intact without overlapping, and to which no nuclear fragments were attached, were measured with automatic segmentation. The reproducibility of the ICM method was verified by reanalyzing one-third of the cases, which disclosed similar results.

\subsection{Ploidy definition}

$F C M$. The histograms were analyzed with reference to the DNA indices of distinguishable stemlines [26]. Histograms with only one modal peak were regarded as DNA diploid (coefficient of variation (CV): 2.8-9.4\%, mean 5.1\%). A tumor was considered to be DNA non-diploid if several peaks were distinguishable. The first peak of the histogram was always regarded as being DNA diploid. The further ranges for DNA indices (DIs) were defined as follows: DNA tetraploid: $1.80<$ DI $<2.20$; DNA aneuploid range: $1.10<$ DI $<1.80$ and DI $\geqslant 2.20$; DNA multiploid: more than one DNA non-diploid stemline. In order to identify a DNA-tetraploid stemline we looked for tetraploid peaks with an integral higher than the integral over the S-fraction of the diploid stemline. If an appurtenant DNA-octaploid G2-peak and also an identifiable S-phase region were present, these high tetraploid peaks were stated to belong to a tetraploid stemline [30]. The percentage of cells in S and G2 phases was analyzed from DNA histograms by use the MULTICYCLE computer program (Phoenix Flow System). Since cell nuclei, and not the whole cells, were measured, mitotic figures were washed out during preparation and were not included in the measurements.

ICM. A tumor was considered to be in the DNA diploid range if only one peak was present $(\mathrm{CV}$ : 4.5-14.9\%, mean $10.7 \%$ ). If more than one peak could be identified, the first peak of the histogram was considered to be in the DNA diploid range and served for calculation of the DNA ploidy and the coefficient of variation. When more than $10 \%$ of the nuclei were found in the DNA tetraploid region $(2 \times 2 \mathrm{c} \pm 2 \times \mathrm{CV})$ the tumor was considered to be in the DNA tetraploid range. DNA polyploid tumors had a significant peak in the multiple of 2c. A tumor was classified as DNA aneuploid either if the DNA content of 4 or more cells exceeded the 5c value according to Böcking [5] or if a prominent peak was identified between $2 \mathrm{c}$ and $4 \mathrm{c}$.

\subsection{Statistics}

The Mann-Whitney rank-sum test was used to compare the distributions of continuous variables. This non-parametric method was chosen as the values for the variables did not follow a normal distribution.

For two-way frequency tables, Fisher's exact test (2-tailed) was used. The interrelationship between continuous variables was estimated with the Spearman correlation coefficient [15]. The probabilities of surviving were calculated with the Kaplan-Meier product-limit method. The differences between the survival curves were tested by the log-rank test [40]. The Cox proportional hazards model was used to analyze the simultaneous importance of several prognostic factors [14]. The proportional assumption in the Cox model was examined with plots [15]. The Wald test was used for the significance test of the regression coefficients [15]. The following strategy was followed due to many candidate variables available: for continuous variables, cutoffs, reported by other investigators, were tested in univariate survival analyses. The other continuous variables were grouped into quartiles and univariate survival analyses were performed. Finally, a two-grouping was selected from these analyses. Only significant variables/cutoffs were included in the final regression analysis.

The statistical software of BMDP (PC-90) was used [15]. 


\section{Results}

\subsection{Clinical features}

The series comprised 23 females and 26 males. The median age was 32 years (range 7-81 years). The sites of the primary tumors were as follows: lower extremity $(n=31)$, upper extremity $(n=8)$, and trunchus $(n=10)$. The thigh $(n=12)$ was the most frequent single location. Nine of the tumors were intracompartmental and 40 were extracompartmental. None of the tumors was restricted to the subcutaneous compartment.

The most common initial symptom was the presence of a palpable painless mass (25 patients), followed by pain (15 patients). The median duration of symptoms was 10 months (range 1-96 months). Initial presentation and duration of symptoms was unknown in 9 cases.

The median tumor size was $6 \mathrm{~cm}$ (range 1-25 cm). Twenty-four tumors were $5 \mathrm{~cm}$ or smaller. All patients were initially treated by surgery. Adequate margins (wide, $n=14$; and amputation, $n=8$ ) were achieved in 22 cases and inadequate margins (intralesional, $n=1$; and marginal, $n=24$ ) in 25 cases. In two cases the surgical margins were unknown. Twenty-three patients received some form of adjuvant therapy: postoperative radiotherapy, $n=17$; adjuvant chemotherapy, $n=5$; and radioand chemotherapy, $n=1$.

Local recurrences were diagnosed in 15 patients and distant recurrences (lung metastases) in 29 patients, including 11 patients with prior local recurrence. Synchronous (local and lung) recurrences were diagnosed in one patient. The relapse-free survival rate (to local recurrence or metastasis) was $34 \%$ at 5 years $(95 \%$ confidence interval (CI), 20-48\%). The local recurrence-free (metastatic relapses treated as censored observations) and the metastasis-free survival rates (local relapses treated as censored observations) were 69\% (95\% CI, 55-83\%) and 60\% (95\% CI, 46-74\%) at 5 years, respectively.

The median follow-up time after initial treatment was 51 months (range 6-276 months). Twenty patients were alive with no evidence of disease, 5 were alive with disease, 22 were dead due to the tumor, and 2 were lost for follow-up. The overall 5 -year survival after initial treatment was $64 \%$ (95\% CI, 50-78\%).

\subsection{Light microscopic features}

Seven of the BSS were of the classical type and 12 showed focal biphasia. More than $50 \%$ of solid/glandular areas were observed in 5 BSS. All MSS were of the fibrous variant. None of the cases showed presence of rhabdoid cells. Median mitotic rate was 4/10 HPF (range 0-67/10 HPF). Fifteen cases showed mitotic rates higher than 10/10 HPF, and in 8 of them it was higher than 15/10 HPF.

Necrosis was present in 26 cases and occupied more than $15 \%$ of the tumor volume in 22 cases. Focal $(n=10)$ or moderate $(n=3)$ calcification was present in 13 cases. Focal $(n=3)$, moderate $(n=3)$ or extensive $(n=7)$ hemangiopericytic areas were observed in 13 cases. The amount of mast cells $(n=40)$ was 11/10 HPF (range 0-467/10 HPF). Usually, an accumulation of mast cells were observed at the periphery of the tumor and only in some cases were mast cells scattered throughout the tumor. The amount of mast cells was higher than 10/10 HPF in 22 cases, and higher than 20/10 HPF in 17. Tumor cells in blood vessels were observed in 7 cases. Focal $(n=7)$ or extensive $(n=1)$ areas of tumor tissue were present at the surgical margins in 8 tumors.

The grades of malignancy obtained with the UICC and NCI systems were concordant (grade 2, $n=19$; grade $3, n=18$ ) in 37 cases. The 12 discordant cases comprised 2 tumors grade 1 by UICC 


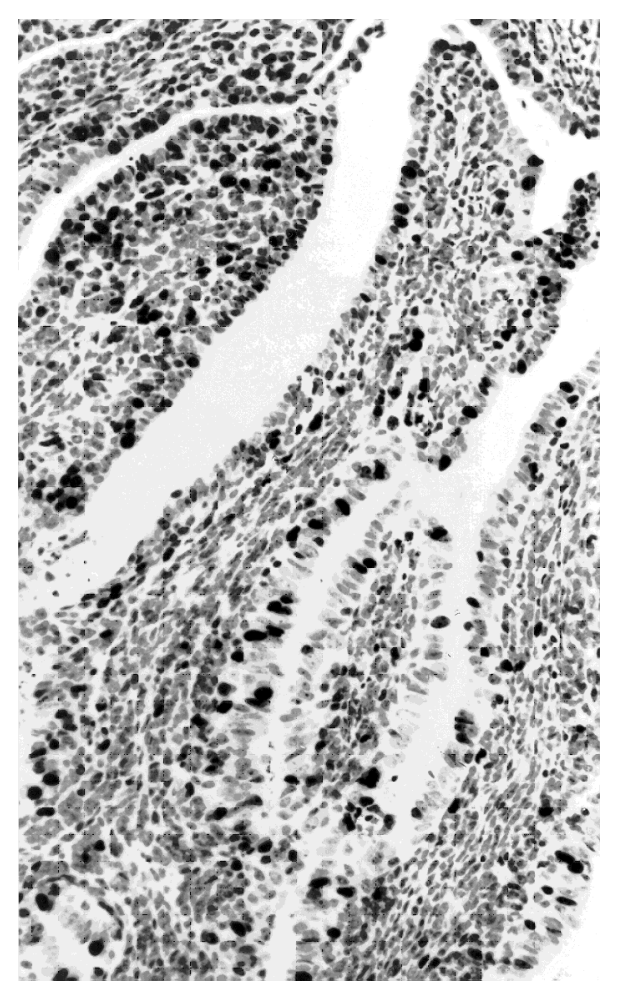

Fig. 1. Biphasic synovial sarcoma displaying prominent PCNA immunoreactivity of the cells lining clefts and glandular spaces. ABC, $280 \times$.

and grade 2 by NCI, 4 grade 2 by UICC and grade 3 by NCI, and 6 grade 3 by UICC and grade 2 by NCI. The mitotic count was low $(<10 / 10 \mathrm{HPF})$ in the 6 cases in which the UICC grade was lower than the NCI grade, and high ( $\geqslant 15 / 10 \mathrm{HPF})$ in the other 6 discordant cases.

\subsection{Immunohistochemistry}

In all but one case immunoreactivity for PCNA and Ki-67 was relatively homogeneous; a BSS showed, with both markers, a higher number of immunoreactive cells in solid/glandular areas than in the surrounding spindle cells (Figs 1 and 2). The median PCNA-LI $(n=40)$ was $14.5 \%$ (range $0.1-48.8 \%)$. Eleven cases showed PCNA-LI higher than 20\%. The median Ki-67-LI $(n=37)$ was $10.7 \%$ (range $0.1-53.8 \%$ ). Twenty cases showed Ki-67-LI higher than $10 \%$.

\subsection{DNA cytometry}

Non-evaluable histograms (due to bad suspensions) were obtained in two cases, one by ICM and another by FCM. DNA ploidy descriptors (DNA diploid, $n=30$; and DNA aneuploid, $n=4$ ) were concordant for the two methods in 34 cases. The 6 discordant cases comprised 4 tumors that were DNA diploid by ICM and DNA aneuploid by FCM, 1 that was DNA tetraploid by ICM and DNA diploid by FCM, and 1 that was DNA aneuploid by ICM and DNA tetraploid by FCM. The 4 cases that were DNA aneuploid by FCM and DNA diploid by ICM had DNA indices in the DNA near-diploid range (Fig. 3). In the case of DNA tetraploid by FCM, the ICM histogram depicted a 5c exceeding 


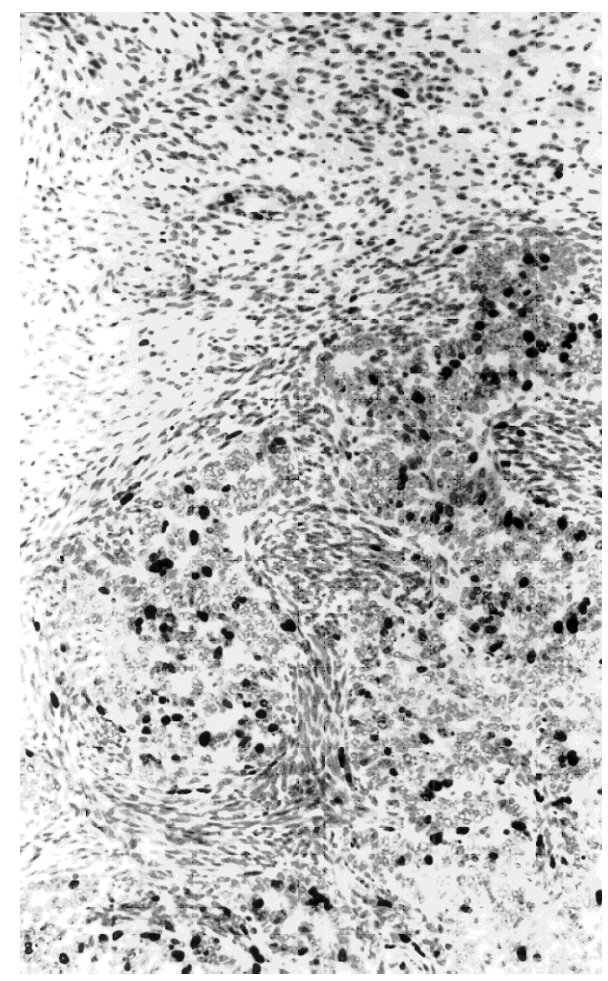

Fig. 2. Biphasic synovial sarcoma displaying Ki-67 immunoreactivity almost exclusively in cells of solid/glandular areas. $\mathrm{ABC}, 280 \times$.
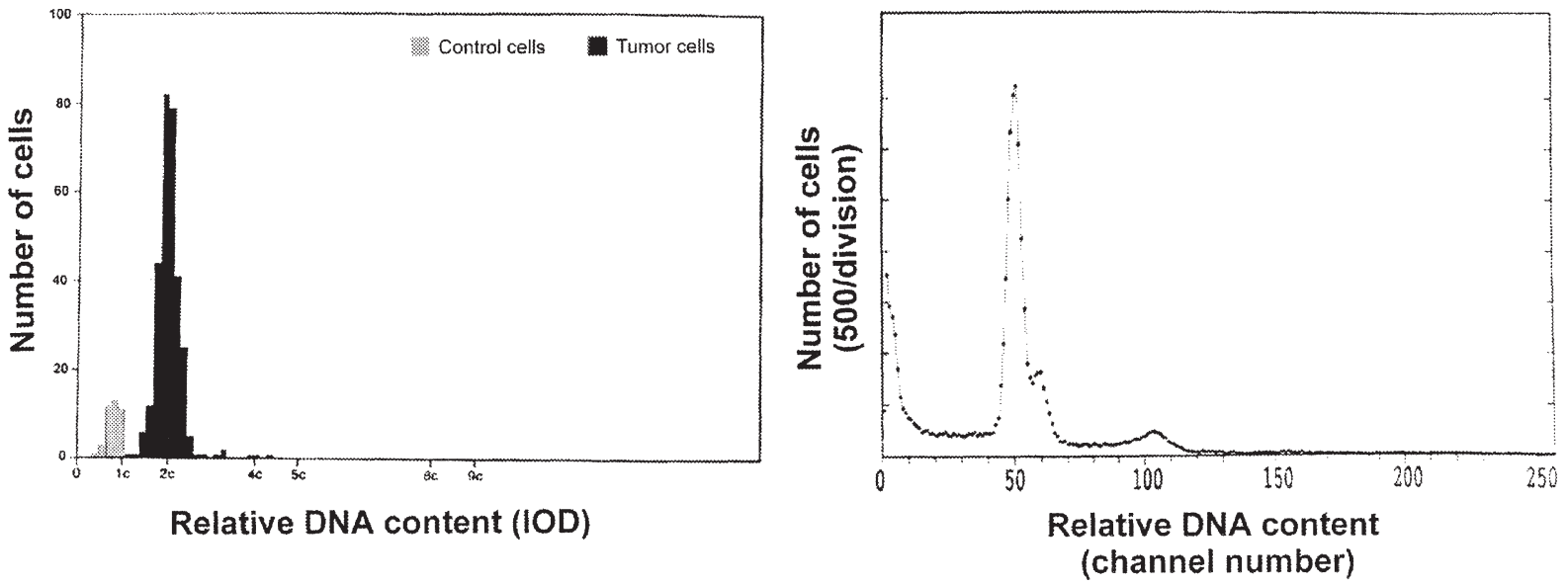

Fig. 3. Diploid DNA histogram by ICM (left) and aneuploid (near-diploid range) by FCM (right) of a synovial sarcoma.

rate (Fig. 4). The case which was DNA diploid by FCM showed a DNA tetraploid population higher than $10 \%$ by ICM.

Whenever DNA aneuploidy was observed by any of the two methods it was used as such for survival evaluation. The calculations of percentages of cells in S and G2 phases of the cell cycle were not possible in 5 cases due to overlapping of G2 peaks of DNA diploid and DNA aneuploid cells, or 

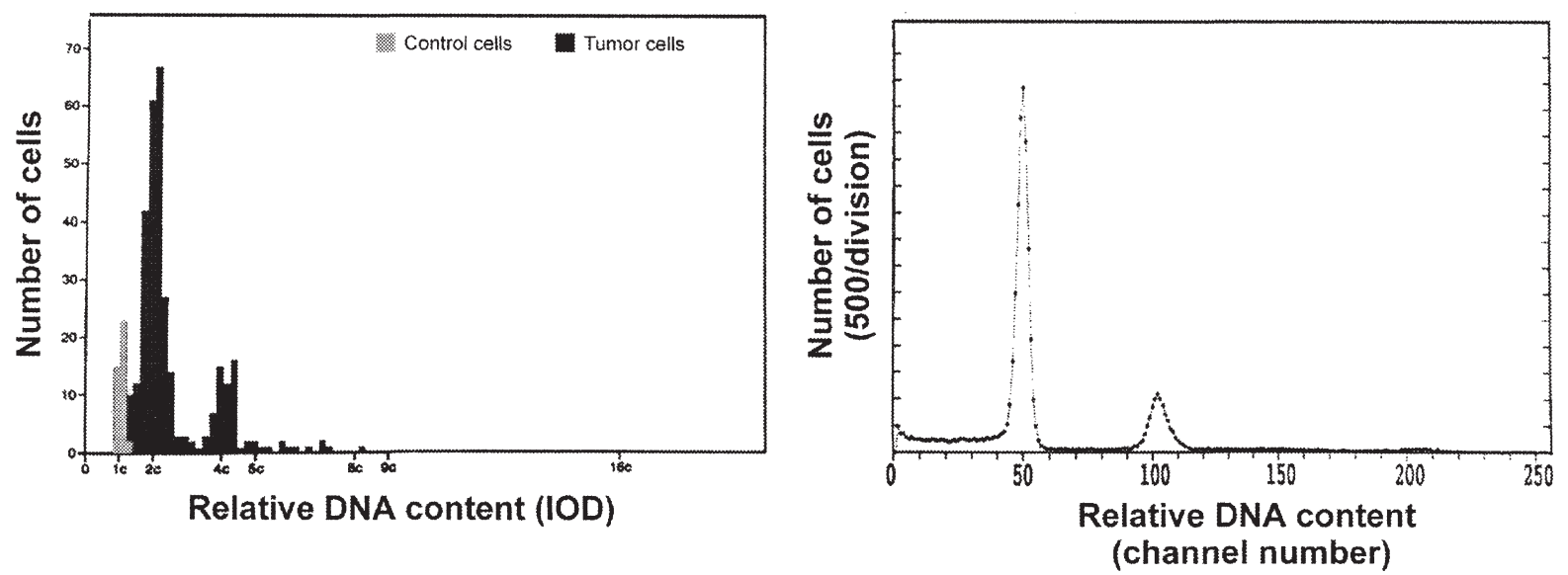

Fig. 4. Aneuploid DNA histogram by ICM (left) and tetraploid by FCM (right) of a synovial sarcoma.

Table 1

Correlation between mitotic rate, Ki-67-LI and PCNA-LI

\begin{tabular}{lccc}
\hline Spearman's rho & Mitotic rate & Ki-67-LI & PCNA-LI \\
\hline Correlation coefficient & & & \\
$\quad$ Mitotic rate & 1.000 & $0.663^{* *}$ & $0.485^{* *}$ \\
$\quad$ Ki-67 & $0.663^{* *}$ & 1.000 & $0.655^{* *}$ \\
PCNA & $0.485^{* *}$ & $0.655^{* *}$ & 1.000 \\
$\quad$ & & & \\
p-value & & 0.000 & 0.001 \\
Mitotic rate & 0.000 & & 0.000 \\
Ki-67 & 0.001 & 0.000 & \\
PCNA & & & \\
& & & \\
Mitotic rate & 49 & 37 & 40 \\
Ki-67 & 37 & 49 & 37 \\
PCNA & 40 & 37 & 49 \\
\hline
\end{tabular}

${ }^{* *}$ Correlation is significant at the 0.01 level (2-tailed).

Ki-67-LI, Ki-67 labeling index; PCNA-LI, proliferating cell nuclear antigen labeling index.

due to small G2 peaks. Median percentage of cells in S-phase $(n=36)$ was $9.1 \%$ (range $1.4-40.4 \%$ ) and the median percentage of cells in G2-phase $(n=36)$ was $13.8 \%$ (range $7.8-66.7 \%$ ).

\subsection{Correlation between proliferation markers (mitotic rate, Ki-67-LI and PCNA-LI)}

Correlation between proliferative markers (mitotic rate, Ki-67-LI and PCNA-LI) are summarized in Table 1. All the aforementioned correlations (Spearman rank correlation coefficients) were positive and attained a significant level $(p<0.001)$.

\subsection{Univariate analysis}

The results of the univariate analysis of clinicopathologic features in relation to survival are summarized in Table 2.

Gender of the patients, compartmentalization and location, dimension, extent of calcification and of hemangiopericytic areas, percentage of glandular areas, blood vessel invasion, adequacy of surgical 
Table 2

Univariate survival analysis of clinicopathologic features in patients with localized synovial sarcoma

\begin{tabular}{|c|c|c|c|c|c|c|}
\hline \multirow[t]{2}{*}{ Features } & \multirow[t]{2}{*}{ Groups } & \multirow[t]{2}{*}{ Parameters } & \multirow[t]{2}{*}{ No. } & \multirow{2}{*}{$\begin{array}{c}\text { Relapse-free } \\
\text { Log-rank } \\
p \text {-value }\end{array}$} & \multicolumn{2}{|c|}{ Overall survival } \\
\hline & & & & & $\begin{array}{c}\text { 5-year } \\
(\%)\end{array}$ & $\begin{array}{c}\text { Log-rank } \\
p \text {-value }\end{array}$ \\
\hline Gender & $\begin{array}{l}\text { Male } \\
\text { Female }\end{array}$ & & $\begin{array}{l}26 \\
23\end{array}$ & 0.56 & & 0.38 \\
\hline Age (years) & $\begin{array}{l}<30 \\
\geqslant 30\end{array}$ & & $\begin{array}{l}23 \\
26\end{array}$ & 0.04 & & 0.28 \\
\hline $\begin{array}{l}\text { Duration of symptoms } \\
\text { (months) }\end{array}$ & $\begin{array}{l}<12 \\
\geqslant 12\end{array}$ & a & $\begin{array}{l}24 \\
16\end{array}$ & $<0.01$ & $\begin{array}{l}49 \\
75\end{array}$ & $<0.05$ \\
\hline Location & $\begin{array}{l}\text { Extremities } \\
\text { Truncal }\end{array}$ & & $\begin{array}{l}39 \\
10\end{array}$ & 0.06 & & 0.09 \\
\hline Compartment & $\begin{array}{l}\text { Compartmental } \\
\text { Extracomparmental }\end{array}$ & & $\begin{array}{r}9 \\
40\end{array}$ & 0.48 & & 0.88 \\
\hline Dimension & $\begin{array}{l}\leqslant 5 \mathrm{~cm} \\
>5 \mathrm{~cm}\end{array}$ & & $\begin{array}{l}24 \\
25\end{array}$ & 0.11 & & 0.88 \\
\hline Surgical margin & $\begin{array}{l}\text { Inadequate } \\
\text { Adequate }\end{array}$ & & $\begin{array}{l}25 \\
22\end{array}$ & 0.21 & & 0.65 \\
\hline Residual tumor & $\begin{array}{l}\mathrm{RO} \\
\mathrm{R} 1+\mathrm{R} 2\end{array}$ & & $\begin{array}{r}41 \\
8\end{array}$ & 0.34 & & 0.26 \\
\hline Adjuvant therapy ${ }^{\mathrm{b}}$ & $\begin{array}{l}\text { No } \\
\text { Yes }\end{array}$ & & $\begin{array}{l}26 \\
23\end{array}$ & 0.77 & & 0.67 \\
\hline Subtype $^{\mathrm{b}}$ & $\begin{array}{l}\text { BSS } \\
\text { MSS }\end{array}$ & a & $\begin{array}{l}19 \\
30\end{array}$ & 0.08 & $\begin{array}{l}56 \\
70\end{array}$ & 0.04 \\
\hline $\begin{array}{l}\text { Glandular } \\
\text { differentiation }\end{array}$ & $\begin{array}{l}<15 \\
\geqslant 15\end{array}$ & & $\begin{array}{r}42 \\
7\end{array}$ & 0.67 & & 0.80 \\
\hline Necrosis & $\begin{array}{l}\text { Absent } \\
\text { Present }\end{array}$ & a & $\begin{array}{l}23 \\
21\end{array}$ & 0.01 & $\begin{array}{l}81 \\
47\end{array}$ & 0.02 \\
\hline $\begin{array}{l}\text { Mitotic rate } \\
(10 \mathrm{HPF})\end{array}$ & $\begin{array}{l}<10 \\
\geqslant 10\end{array}$ & a & $\begin{array}{l}34 \\
15\end{array}$ & $<0.0001$ & $\begin{array}{l}83 \\
22\end{array}$ & $<0.0001$ \\
\hline $\begin{array}{l}\text { Mast cell rate } \\
(10 \mathrm{HPF})\end{array}$ & $\begin{array}{l}<10 \\
\geqslant 10\end{array}$ & a & $\begin{array}{l}18 \\
22\end{array}$ & $<0.0001$ & $\begin{array}{l}24 \\
86\end{array}$ & $<0.001$ \\
\hline Calcification & $\begin{array}{l}\text { Absent } \\
\text { Present }\end{array}$ & & $\begin{array}{l}36 \\
13\end{array}$ & 0.47 & & 0.24 \\
\hline $\begin{array}{l}\text { Hemangiopericytic } \\
\text { areas }\end{array}$ & $\begin{array}{l}\text { Absent } \\
\text { Present }\end{array}$ & & $\begin{array}{l}36 \\
13\end{array}$ & 0.17 & & 0.58 \\
\hline Vessel invasion & $\begin{array}{l}\text { Absent } \\
\text { Present }\end{array}$ & & $\begin{array}{r}42 \\
7\end{array}$ & 0.78 & & 0.90 \\
\hline UICC grade & $\begin{array}{l}1+2 \\
3\end{array}$ & a & $\begin{array}{l}25 \\
24\end{array}$ & $<0.0001$ & $\begin{array}{l}91 \\
29\end{array}$ & $<0.0001$ \\
\hline NCI grade & $\begin{array}{l}2 \\
3\end{array}$ & a & $\begin{array}{l}27 \\
22\end{array}$ & 0.06 & $\begin{array}{l}76 \\
46\end{array}$ & 0.04 \\
\hline Ploidy (FCM/ICM) & $\begin{array}{l}\text { Euploid } \\
\text { Aneuploid }\end{array}$ & a & $\begin{array}{l}32 \\
10\end{array}$ & 0.04 & $\begin{array}{l}72 \\
40\end{array}$ & 0.007 \\
\hline S-phase (\%) & $\begin{array}{l}<10 \\
\geqslant 10\end{array}$ & & $\begin{array}{r}9 \\
27\end{array}$ & 0.95 & & 0.07 \\
\hline S+G2-phase (\%) & $\begin{array}{l}<20 \\
\geqslant 20\end{array}$ & & $\begin{array}{r}28 \\
8\end{array}$ & 0.18 & & 0.25 \\
\hline
\end{tabular}


Table 2

(Continued)

\begin{tabular}{|c|c|c|c|c|c|c|}
\hline \multirow[t]{2}{*}{ Features } & \multirow[t]{2}{*}{ Groups } & \multirow[t]{2}{*}{ Parameters } & \multirow[t]{2}{*}{ No. } & \multirow{2}{*}{$\begin{array}{c}\text { Relapse-free } \\
\text { Log-rank } \\
p \text {-value }\end{array}$} & \multicolumn{2}{|c|}{ Overall survival } \\
\hline & & & & & $\begin{array}{c}\text { 5-year } \\
(\%)\end{array}$ & $\begin{array}{c}\text { Log-rank } \\
p \text {-value }\end{array}$ \\
\hline PCNA-LI & $\begin{array}{l}<20 \\
\geqslant 20\end{array}$ & a & $\begin{array}{l}29 \\
11\end{array}$ & 0.04 & $\begin{array}{l}77 \\
24\end{array}$ & $<0.001$ \\
\hline Ki-67-LI & $\begin{array}{l}<10 \\
\geqslant 10\end{array}$ & a & $\begin{array}{l}17 \\
20\end{array}$ & $<0.0001$ & $\begin{array}{l}88 \\
44\end{array}$ & 0.005 \\
\hline TNM & $\begin{array}{l}\text { I-II } \\
\text { III }\end{array}$ & a & $\begin{array}{l}25 \\
24\end{array}$ & $<0.0001$ & $\begin{array}{l}87 \\
31\end{array}$ & 0.0001 \\
\hline
\end{tabular}

${ }^{\text {a}}$ Parameters associated with short interval-free and overall survival.

${ }^{\mathrm{b}}$ Postoperative radiotherapy and adjuvant chemotherapy were grouped together.

BSS, biphasic synovial sarcoma; MSS: monophasic synovial sarcoma; HPF, high power field; FCM, DNA flow cytometry;

ICM, DNA image cytometry; PCNA-LI, proliferating cell nuclear antigen labeling index; Ki-67-LI, Ki-67 labeling index.

margins, and residual tumor were not significant predictors of survival (relapse-free and overall survival) (Table 2). Young age of the patients $(p=0.04)$, duration of symptoms $(p<0.01)$, UICC grade $(p<0.0001)$, NCI grade $(p=0.06)$, histologic subtype $(p=0.03)$, mitotic rate $(p<0.001)$, amount of mast cells $(p<0.0001)$, necrosis $(p<0.01)$, PCNA-LI $(p=0.04)$, Ki-67-LI $(p<0.0001)$, DNA ploidy $(p=0.04)$, and TNM stage $(p<0.0001)$ were significant predictors of relapse-free survival (to local recurrence or metastasis) (Table 2).

Duration of symptoms $(p<0.05)$, UICC grade $(p<0.0001)$, NCI grade $(p=0.04)$, histologic subtype $(p=0.04)$, mitotic rate $(p=0.01)$, amount of mast cells $(p<0.001)$, necrosis $(p<0.02)$, PCNA-LI $(p<0.001)$, Ki-67-LI $(p=0.005)$, DNA ploidy $(p=0.007)$, and TNM stage $(p=0.0001)$ were significant predictors of overall survival (Table 2).

Short duration of symptoms ( $<12$ months), biphasic type (BSS), scarcity of mast cells $(<10 / 10$ $\mathrm{HPF}$ ), presence of necrosis, high mitotic rate $(\geqslant 10 / 10 \mathrm{HPF})$, high histologic grade (grade 3 ), high PCNA-LI $(\geqslant 20 \%)$, high Ki-67-LI $(\geqslant 10 \%)$, DNA aneuploidy, and advanced TNM stage (stage III) were features associated with significantly shorter relapse-free and significantly shorter overall 5-year survival rates. Young age (younger than 30 years) was a significant predictor of relapse-free survival but not overall survival. The 5-year survival rates of the patients for each of these parameters are given in Table 2.

\subsection{Multivariate analysis}

The results of the multivariate analysis are summarized in Table 3. Amount of mast cells, mitotic rate, or PCNA-LI were significant predictors of survival in addition to TNM stage (Fig. 5). Only one of them at each time provided significant additional information to TNM staging. Curiously, the additional prognosis information provided by the three parameters seemed to be nearly the same.

\subsection{Correlation between mast cell count, mitotic rate, and PCNA-LI}

Correlations between the significant features found in the multivariate analysis are summarized in Table 4.

The amount of mast cells was significantly correlated with mitotic rate $(p=0.003)$ and PCNA-LI $(p=0.04)$. Tumors with mast cell count less than 10/10 HPF had frequently higher mitotic rates $(\geqslant 10 / 10 \mathrm{HPF})$ and high PCNA-LI $(\geqslant 20 \%)$. In addition, the median mitotic rate and the median 
Table 3

Multivariate survival analysis (Cox model) in patients with localized synovial sarcoma using 3 alternative models

\begin{tabular}{lcccc}
\hline $\begin{array}{l}\text { Prognostic } \\
\text { factors }\end{array}$ & $\begin{array}{c}\text { Regression } \\
\text { coefficient }\end{array}$ & $\begin{array}{c}\text { Relative } \\
\text { death risk }\end{array}$ & $95 \%$ CI & $\begin{array}{c}\text { Wald test } \\
p \text {-value }\end{array}$ \\
\hline $\begin{array}{l}\text { Group } 1, n=40 \\
\text { TNM: III vs. I-II }\end{array}$ & 1.3 & 3.5 & $1.2-10.5$ & $<0.01$ \\
$\quad$ Mast cell rate ${ }^{\mathrm{a}}:<10$ vs. $10+$ & 1.5 & 4.5 & $1.5-13.6$ & $<0.001$ \\
Group 2, $n=49$ & & & & \\
$\quad$ TNM: III vs. I-II & 1.3 & 3.5 & $1.2-10.7$ & $<0.05$ \\
$\quad$ Mitotic rate $:$ 10+ vs. $<10$ & 1.1 & 3.0 & $1.1-8.2$ & $<0.05$ \\
Group 3, $n=40$ & & & & \\
TNM: III vs. I-II & 2.1 & 8.4 & $2.6-26.7$ & $<0.001$ \\
PCNA-LI: 20\%+ vs. $<20 \%$ & 2.1 & 7.9 & $2.7-23.0$ & $<0.001$ \\
\hline
\end{tabular}

${ }^{a}$ Per 10 high power fields.

CI, confidence interval; PCNA-LI, proliferating cell nuclear antigen labeling index.
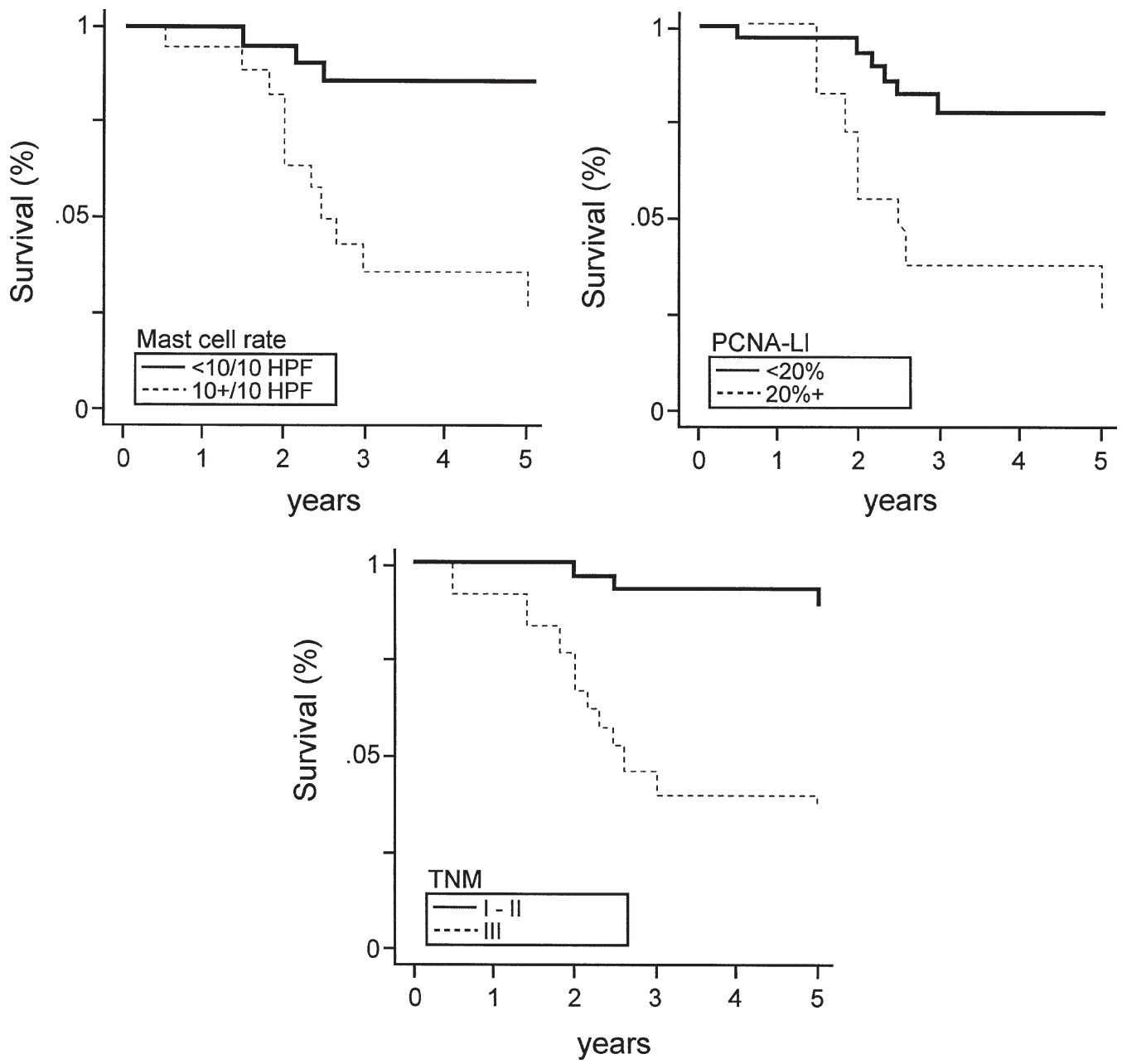

Fig. 5. Survival curves of patients with synovial sarcoma stratified by amount of mast cells, PCNA labeling index, and TNM staging. 
Table 4

Relationship between the amount of mast cells, mitotic rate ans PCNA-LI in synovial sarcoma

\begin{tabular}{cccc}
\hline & \multicolumn{2}{c}{ Mast cell rate } & \multirow{2}{*}{$p$-value } \\
\cline { 2 - 3 } & $<10 / 10 \mathrm{HPF}(n=18)$ & $\geqslant 10 / 10 \mathrm{HPF}(n=22)$ & \\
\hline Mitotic rate & 7 & 19 & $0.003^{*}$ \\
$<10 / 10 \mathrm{HPF}$ & 11 & 3 & $0.003^{* *}$ \\
$\geqslant 10 / 10 \mathrm{HPF}$ & 12.5 & 2.5 & \\
Median (\%) & & & $0.04^{*}$ \\
PCNA-LI & 10 & 19 & \\
$\quad<20 \%$ & 8 & 3 & $0.03^{*}$ \\
$\geqslant 20 \%$ & 18.1 & 7.5 & \\
Median $(\%)$ & & &
\end{tabular}

HPF, high power field; PCNA-LI, proliferating cell nuclear antigen labeling index.

${ }^{*}$ Fisher's exact test (2-tailed); ${ }^{* *}$ Mann-Whitney rank-sum test.

PCNA-LI were significantly higher ( $p=0.003$ and $p=0.03$, respectively) in tumors containing few mast cells compared to tumors containing numerous mast cells. The Spearman rank correlation coefficient between mitotic rate and amount of mast cells was -0.49 , and between PCNA-LI and amount of mast cells -0.42 .

\section{Discussion}

Synovial sarcoma (SS) is a rare soft tissue tumor, usually of high grade malignancy. Since 1980 all but one series on record dealing with survival rates are based upon less than 100 cases $[6,8,12,20$, $22,23,25,29,32-34,37,41,44,46,47,50,52,56]$.

The 5-year survival rates range from 30.0 to $82.6 \%$. The $64 \%$ 5-year survival rate observed in the present series of localized SS is within the range of the series previously reported (Table 5) $[6,8,12$, $20,22,23,25,29,32-34,37,41,44,46,47,50,52,56]$.

By using the TNM staging system [28] we found, as in other studies of soft tissue sarcomas including SS [36,39], that stage is a powerful prognosticator of relapse-free and overall survival. Actually, in our series of localized SS, patients with tumors at TNM stages I-II at presentation had a much better prognosis than patients with tumors at TNM stage III.

Favorable clinical features previously reported include gender $[8,36,41,52]$, young age $[8,17,37,52]$, duration of symptoms, location of the tumors in the extremities [8,33,37,41,52], and a small size (less than $5 \mathrm{~cm}$ ) of the tumors $[6,17,20,37,39,41,43,52,56]$. Out of the five aforementioned features only duration of symptoms (more than 12 months) turned out to be a favorable factor for relapse-free (to local or metastatic recurrence) and overall survival in the univariate analysis of our series. Patients of young age (less than 30 years) had a longer relapse-free period but not longer overall survival. Our results are therefore consistent with those of others that did not find a significant association between age $[6,20,22,25,36,43,56]$, gender $[6,17,22,25,43,56]$, tumor location $[6,25,36]$ and tumor size $[22,25]$, and survival of patients with SS.

In the present series, compartmental location of the tumor, adequacy of surgical margins, and adjuvant treatment (radiotherapy or chemotherapy) did not predict significantly the relapse-free and overall survival of patients with SS. Also, the residual tumor at the surgical margins, positive only in 8 cases $(16.3 \%)$, turned out not to be a prognostic marker for overall survival. The 5-year relapse-free rate of our series (34\%) is within the range of previously reported results $(21.2-44.4 \%)$ regarding the 
Table 5

5-year survival in 19 series of synovial sarcoma

\begin{tabular}{clcc}
\hline Year & Series & Number of patients & 5-year overall survival (\%) \\
\hline 1981 & Buck et al. [15] & 33 & 36.0 \\
1982 & Wright et al. [52] & 185 & 38.0 \\
1982 & Varela-Duran et al. [50] & 26 & 82.6 \\
1983 & Tsuneyoshi et al. [47] & 17 & 51.0 \\
1984 & Zito et al. [56] & 48 & 50.0 \\
1984 & Rapjal et al. [41] & 52 & 43.5 \\
1987 & Collin et al. [12] & 63 & 56.0 \\
1988 & Tsujimoto et al. [46] & 26 & 44.9 \\
1989 & Lack et al. [32] & 50 & 55.0 \\
1990 & Golouh et al. [22] & 36 & 64.0 \\
1991 & Henderson et al. [25] & 20 & 43.0 \\
1992 & Brodsky et al. [6] & 95 & 59.0 \\
1992 & Hashimoto et al. [23] & 73 & 52.0 \\
1992 & Santavirta [44] & 31 & 55.0 \\
1992 & Ivanov-Dutescu et al. [29] & 46 & 30.0 \\
1993 & Lee et al. [34] & 18 & 78.4 \\
1993 & Oda et al. [37] & 56 & 54.0 \\
1993 & Ladenstein et al. [33] & 31 & 73.5 \\
1993 & Fetch et al. [20] & 27 & 50.0 \\
\hline
\end{tabular}

control of local and distant disease in SS [29,34,41]. Recently, Ladenstein et al. [33] reported 74.2\% 5-year event-free survival in a multicenter trial including 31 pediatric patients with SS.

Although we found in the univariate analysis that the BSS subtype indicates a shorter relapse-free and overall survival, we observed, like others $[6,10,17,22,23,25,33,38,39,43]$, that histologic subtype was not a significant prognostic factor in the multivariate analysis. In agreement with others $[22,37$, $43,52]$ and in contrast to Cagle et al. [10], we observed no relationship between the extent of glandular differentiation and the overall survival.

Both calcification [50] and poor differentiation [19] in SS are among the morphological features reported to be related to the prognosis. Calcification is frequently seen in SS [19]. Extensive calcification was reported by Varela-Duran and Enzinger to be associated with a good prognosis [50]. However, in our series, no relationship between calcification and survival of the patients was observed. On the other hand, none of the cases in our series showed more than a moderate extent of calcification.

Hemangiopericytic pattern is one of the features described in poorly differentiated SS and is thought to be associated with an unfavorable prognosis [19]. None of the cases in our series was classified as poorly differentiated, and the extent of hemangiopericytic pattern was not predictive for the overall survival.

We have found, like other authors in several series of different types of soft tissue sarcomas [49], and Oda et al. [37] in SS specifically, that a large amount of mast cells is a favorable prognostic feature. The prognostic significance of this feature was maintained in the multivariate analysis in our study.

The frequent presence of perivascular and interstitial mast cells has been described as a characteristic feature of some benign (e.g., schwannomas, hemangiomas and cellular dermatofibromas) and malignant (e.g., neurofibrosarcomas, synovial sarcomas and malignant fibrous histiocytomas) soft tissue tumors $[19,49]$. It has also been described elsewhere in other neoplasms such as breast carcinoma and cervical carcinoma. It is interesting that, as we observed in the present study and as has been reported previously in several types of soft tissue tumors, mast cells are preferentially located in the peripheral areas of the neoplastic masses displaying active tumor growth. 
The putative role of mast cells in tumor growth remains to be clarified. There are experimental studies favoring an involvement of mast cells in tumor suppression [9]. In contrast to these studies, Roche [42] reported that mast cells enhance tumor proliferation of transplanted sarcomas in mice. We observed that the amount of mast cells showed a significant inverse correlation with proliferation markers (mitotic rate and PCNA-LI). Moreover, the amount of mast cells was a significant predictor of the disease-free interval and the overall survival of the patients. Thus, mast cells may be involved in suppression of tumor growth.

Extent of necrosis has been reported as an important prognostic factor in series composed of different types of soft tissue sarcomas [13,19,23,32] and also in SS [22,23,37,38,43]. Despite having observed a significant relationship between necrosis and overall survival in the univariate analysis we, like Oda et al. [37,38], failed to confirm such a relationship at the multivariate analysis.

The importance of the mitotic rate prognostic factor reported in the present series after multivariate analysis corroborates Enzinger's statement [19] on the existence of "an inverse correlation between survival and mitotic activity" in SS, and concurs also with the reports of other groups [10,17,20,22, $25,37,38,43,56]$.

Histologic grading of soft tissue sarcomas is a matter of great controversy $[13,19,32,46]$. There are several grading systems using different criteria and variable thresholds for each of them $[13,19,28]$. Our results are consistent with those of Moberger et al. [36] and with the results recently reported by Pappo et al. [39], showing that grading of SS is of prognostic value.

We compared the prognostic strengths of the UICC [28] and the NCI [13] grading systems, and the former system appeared to be better in our study. By using the UICC grading system we showed that the mitotic rate, which is not used in the NCI system for SS, is important in the grading of SS. The results we have obtained using the UICC system comply with the existence of a spectrum (from 1 to 3, in a grade scale) of malignancy in SS, as outlined by Enzinger [19]. At variance with this, with the NCI grading system SS are always high grade tumors (grades 2-3), depending on the extent of gross and microscopical necrosis (15\% threshold). Moreover, in our multivariate analysis, necrosis did not significantly predict the survival probability, thus contributing to weakening the potential strength of the NCI grading system.

We observed blood vessel invasion in 7 cases. This feature was not associated with a statistically significant difference on the survival, as was described by Rööser et al. in SS [43], and at variance to the results reported by other groups in series composed of different types of soft tissue sarcoma $[19,32]$.

The results of DNA cytometry parameters obtained to date are controversial partly because one tends to confound univariable analysis with multivariate analysis $[2,17,38,53]$. In our series, less than $1 / 4$ of the cases were DNA aneuploid. This percentage is smaller than that reported by other authors. In fact, taking together the data reported in several series dealing with SS, the overall percentage of DNA aneuploid SS is $40 \%$ (out of 116 SS) $[3,17,38]$.

No association between prognosis and DNA ploidy has been observed in several studies $[19,38,53]$, whereas in other reports $[1,2,17]$ DNA aneuploidy has been found to be an unfavorable prognostic factor for patients with soft tissue sarcomas in general. In our univariate analysis we observed, as did Oda et al. [38], an association between DNA aneuploidy and an unfavorable prognosis. However, at variance with the findings of El-Naggar et al. [17] and Akkerman et al. [2], this association was lost in the multivariate analysis, as was also described by Oda et al. [38]. Moreover, the evaluation of the percentage of tumor cells in $\mathrm{S}$ and $\mathrm{S}+\mathrm{G} 2$ phases did provide any significant additional prognostic information (Oda et al. [38], present study). 
In our series, DNA ploidy was studied by image (ICM) and flow (FCM) cytometry. The concordance rate of DNA ploidy descriptors observed in the present series fits with other reports [1]. In these studies, examples of discordance between DNA ploidy descriptors (DNA diploid by FCM and DNA aneuploid by ICM and vice-versa) have been reported. Several explanations have been advanced to explain such discordances: inherent differences in the two methods, problems at the histogram interpretation level, differences in tissue sampling, and intratumor heterogeneity. In addition, the possible effect of formalin fixation as a limiting factor in DNA cytometry evaluation should be considered, as has been recently pointed out by Zalupski et al. in a series of soft tissue sarcomas studied by FCM [54]. This last point may indeed play a major role in the controversial data on record since it is known that percentage of S-phase cells assessed on paraffin material tends to differ from series to series due to differences in several procedures: fixation, embedding and cutting.

Few studies on the prognostic value of PCNA expression in soft tissue sarcomas have been reported to date. High PCNA expression was found to be associated with a poor prognosis in a series of hemangiopericytomas [53] and in a series of different types of soft tissue sarcomas [7]. No significant association between PCNA expression and survival was observed in a series of different types of soft tissue sarcomas [4] and in a series of malignant fibrous histiocytoma (MFH) [51]. High PCNA expression was associated with a better prognosis in a series of rhabdomyosarcomas [31].

The PCNA labeling index remained a statistically significant prognostic factor in our multivariate analysis as was reported by Oda et al. [38].

There are few reported studies on the prognostic value of Ki-67 expression in soft tissue sarcomas. In one study dealing with $\mathrm{MFH}$, the expression of Ki-67 was not significantly associated with prognosis [55]. In other studies, high Ki-67 levels were found to be an unfavorable prognostic factor for patients with soft tissue sarcomas [16,48].

To the best of our knowledge, this is the first report on the prognostic value of Ki-67 in SS. In the univariate analysis, high Ki-67-LI was associated with an unfavorable prognosis. However, this association did not attain the threshold of statistical significance in the multivariate analysis.

\section{Conclusion}

Besides TNM (UICC) stage, our study revealed several factors significantly associated with the survival of patients with localized SS in the univariate analysis.

Amount of mast cells, mitotic rate or PCNA-LI remained as significant prognosticators, in addition to staging, at the multivariate analysis level. Further studies are needed to clarify the putative relationship between mast cell abundance and proliferation markers.

\section{Acknowledgements}

We thank Ellen Hellesylt, Metter Myre, Inger Liv Nordli, Elisabeth Mølsted and Ruth Puntervold for expert technical assistance, and Wencke Danielsen and Ellen Nygaenen for expert secretarial assistance.

\section{References}

[1] V. Agarwall, E. Greenebaum, R. Wersto and L. Koss, DNA ploidy of spindle cell soft-tissue tumors and its relationship to histology and clinical outcome, Arch. Pathol. Lab. Med. 115 (1991), 558-569. 
[2] M. Åkerman, H. Willén, M. Ferno, P. Gustafson and A. Rydholm, Prognostic importance of DNA ploidy in soft tissue sarcoma (abstr.), Acta Orthop. Scand. 64(253) (1993), 22-23.

[3] H.C.F. Bauer, A. Kreicbergs and B. Tribukait, DNA content prognostic in soft tissue sarcoma. 102 patients followed for 1-10 years, Acta Orthop. Scand. 62 (1991), 187-194.

[4] C. Black, B.A. Michia, R.P. Reid, J. Paul and A. Barret, Ploidy and proliferation indices in soft tissue tumors and tumor-like lesions. A comparison with histological grade and clinical outcome (abstr.), J. Pathol. 170(Suppl.) (1993), 414.

[5] A. Böking, DNA cytometric diagnosis of prospective malignancy in boderline lesions of the uterine cervix: Recent results, Cancer Res. 122 (1991), 106-115.

[6] A.T. Brodsky, M.E. Burt, S.I. Hajdu, E. Casper and M.F. Brennan, Tendosynovial sarcoma. Clinicopathological features, treatment and prognosis, Cancer 72 (1992), 484-489.

[7] J. Brooks and J. Kobos, Sarcoma prognosis: Impact of proliferative markers, HLA-Dr reactivity and mast cell content (abstr.), Lab. Invest. 68 (1993), 5.

[8] P. Buck, R. Mickelson and M. Bonfoglio, Synovial sarcoma: A review of 33 cases, Clin. Orthop. 156 (1981), 211-215.

[9] C. Burtin et al., Inverse correlation between tumor incidence and tissue histamine levels in W/Wv, Wv/t, and $+/+$ mice, JNCI 74 (1985), 671-674.

[10] L.A. Cagle, J.M. Mirra, F.K. Storm, D.J. Roe and F.R. Eilber, Histological features relating to prognosis in synovial sarcoma, Cancer 59 (1987), 1810-1814.

[11] G. Cattoretti et al., Monoclonal antibodies against recombinant parts of Ki-67 antigen (MIB1 and MIB3) detect proliferating cells in microwaved-processed formalin-fixed paraffin sections, J. Pathol. 168 (1992), 357-363.

[12] C. Collin et al., Localized extremity soft-tissue sarcoma: An analysis of factors affecting survival, J. Clin. Oncol. 5 (1987), 601-612.

[13] J. Costa, R.A. Wesley, E. Glatstein and S.A. Rosenberg, The grading of soft tissue sarcomas. Results of a clinicohistopathologic correlation in a series of 163 cases, Cancer 53 (1984), 530-541.

[14] D.R. Cox, Regression models and life-tables, J. Roy. Stat. Soc. B 34 (1972), 187-220.

[15] W.J. Dixon, M.B. Brown, L. Engelman and R.L. Jenneric, eds, BMDP Statistical Software Manual, University of California Press, Berkley, 1990.

[16] M. Drobnjak et al., Prognostic implications of p53 nuclear overexpression and high proliferation index of Ki-67 in adult soft-tissue sarcomas, JNCI 86 (1994), 549-554.

[17] A.K. El-Naggar et al., Synovial sarcoma. A DNA flow cytometric study, Cancer 65 (1990), 2295-2300.

[18] W.F. Enneking, S.S. Spanier and M.A. Goodman, A system for the surgical staging, of musculoskeletal sarcoma, Clin. Orthop. 153 (1980), 106-120.

[19] F.M. Enzinger and S.W. Weiss, Soft Tissue Tumors, 3rd edn, CV Mosby, St. Louis, 1995.

[20] J.F. Fetsch and J.M. Meis, Synovial sarcoma of the abdominal wall, Cancer 72 (1993), 469-477.

[21] S.D. Fossa, E. Thorud, M.C. Shoaib, E.O. Pettersen, J. Hoie and O. Scott-Knudsen, DNA flow cytometry in primary breast carcinoma, APMIS 92 (1986), 475-480.

[22] R. Golouh, V. Vuzevski, M. Bracko, R.O. Heul and J. Cervek, Synovial sarcoma. A clinicopathological study of 36 cases, J. Surg. Oncol. 45 (1990), 28-90.

[23] H. Hashimoto, Y. Daimaru, S. Takeshita, M. Tsuneyoshi and M. Enjoji, Prognostic significance of histologic parameters of soft tissue sarcomas, Cancer 70 (1992), 2822-2861.

[24] D.W. Hedley, M.L. Friedlander, I.W. Taylor, C.A. Rugg and E.A. Musgrove, Method for analysis of cellular DNA content of paraffin embedded pathological material using flow cytometry, J. Histochem. Cytochem. 31 (1983), 13331335 .

[25] S.A. Henderson, R. Davis and J.R. Nixon, Synovial sarcoma: A clinicopathological review, Int. Orthop. 15 (1991), 251-255.

[26] W. Hiddeman et al., Convention on nomenclature for DNA cytometry, Cancer Genet. Cytogenet. 13 (1984), 181-183.

[27] S.-M. Hsu, L. Raine and H. Fanger, A comparative study of the peroxidase-antiperoxidase method and an avidinbiotin complex method for studying polypeptide hormones with radioimmunoassay antibodies, Am. J. Clin. Pathol. 75 (1981), 734-738.

[28] International Union Against Cancer, TNM Classification of Malignant Tumours, P. Hermanek and L.H. Sobin, eds, 4th edn, Springer, Berlin, 1987.

[29] R. Ivanov-Dutescu, B. Tomeno and F. Mallet, Synovialsarcome. Etude d'une serie de 46 cas, Rev. Chir. Orthop. 78 (1992), 1-7.

[30] A.B. Jacobsen, S.D. Foss, E. Thorud, S. Lunde, J.E. Melvik and E.O. Pettersen, DNA flow cytometric values in bladder carcinoma biopsis obtained from fresh and from paraffin embedded material, APMIS 96 (1988), 25-29.

[31] A. Karameris, J. Miser and M. Tsokos, Proliferating cell nuclear antigen (PCNA) in childhood rhabdomyosarcoma (abstr.), Lab. Invest. 68 (1993), 7. 
[32] E.E. Lack et al., Extremity soft tissue sarcomas: Analysis of prognostic variables in 300 cases and evaluation of tumor necrosis as a factor in stratifying higher-grade sarcomas, J. Surg. Oncol. 41 (1989), 263-273.

[33] R. Ladenstein et al., Synovial sarcoma of childhood and adolescence. Report of the German CWS-81 study, Cancer 71 (1993), 3647-3655.

[34] S.-Y. Lee, D.-G. Jeon and S.-S. Kim, Synovial sarcoma of the extremities, Int. Orthop. 17 (1993), 293-296.

[35] T. Lindmo and H.B. Steen, Characteristics of a simple high resolution flow cytometry based on a flow configuration, Biophys. J. 28 (1979), 33-44.

[36] G. Moberger, U. Nilsonne and S. Friberg, Jr., Synovial sarcoma: Histologic features and prognosis, Acta Orthop. Scand. 111(Suppl.) (1968), 3-38.

[37] Y. Oda, H. Hashimoto, M. Tsuneyoshi and S. Takeshita, Survival in synovial sarcoma. A multivariate study of prognostic factors with special emphasis on the comparison between early death and long-term survival, Am. J. Surg. Pathol. 17 (1993), 35-44.

[38] Y. Oda, H. Hashimoto, S. Takeshita and M. Tsuneyoshi, The prognostic value of immunohistochemical cell nuclear antigen in synovial sarcoma, Cancer 72 (1993), 478-485.

[39] A. Pappo, J. Fontanesi, C. Hurwitz, X. Rao, D. Parham and C. Pratt, Synovial sarcoma in children and adolescents. The St. Jude experience (abstr.), Proc. ASCO 13 (1994), 413.

[40] R. Peto et al., Design and analysis of randomized clinical trials requiring prolonged observation of each patient, $B r$. J. Cancer 35 (1977), 1-39.

[41] S. Rapjal, R.H. Moore and C.P. Karakousis, Synovial sarcoma. A review of treatment and survival in 52 patients, $N Y$ State J. Med. 84 (1984), 17-19.

[42] W.R. Roche, The nature and significance of tumour-associated mast cells, J. Pathol. 148 (1986), 175-182.

[43] B. Rööser, H. Willén, A. Hugoson and A. Rydholm, Prognostic factors in synovial sarcoma, Cancer 63 (1989), 2182-2185.

[44] S. Santavirta, Synovial sarcoma. A clinicopathological study of 31 cases, Arch. Orthop. Trauma. Surg. 11 (1992), $155-159$.

[45] S.R. Shi, M.E. Key and K.L. Kalra, Antigen retrieval in formalin-fixed paraffin-embedded tissues: An enhancement method for an immunohistochemical staining based on microwave oven heating of tissue sections, J. Histochem. Cytochem. 39 (1991), 741-748.

[46] M. Tsujimoto, K. Aozasa, T. Ueda, Y. Morimura, Y. Komatsubara and T. Doi, Multivariate analysis for histologic prognostic factors in soft-tissue sarcomas, Cancer 62 (1988), 994-998.

[47] M. Tsuneyoshi, K. Yokoyama and M. Enjoji, Synovial sarcoma. A clinicopathological and ultrastructural study of 42 cases, Acta Pathol. Jpn. 33 (1983), 93-96.

[48] T. Ueda et al., Prognostic significance of Ki-67 reactivity in soft tissue sarcomas, Cancer 63 (1989), 1607-1611.

[49] T. Ueda et al., Prognostic significance of mast cells in soft tissue sarcoma, Cancer 62 (1988), 2416-2419.

[50] J. Varela-Duran and F.M. Enzinger, Calcifying synovial sarcoma, Cancer 50 (1982), 345-352.

[51] J. Willis et al., Proliferating cell nuclear antigen (PCNA) expression in malignant in malignant fibrous histiocytoma: An immunocytochemical analysis of 18 cases (abstr.), Lab. Invest. 66 (1992), 11.

[52] P.H. Wright, F.H. Sim, E.H. Soule and W.F. Taylor, Synovial sarcoma, J. Bone Joint Surg. 64A (1982), 112-122.

[53] C.C.-W. Yu et al., Haemangiopericytomas: The prognostic value of immunohistochemical staining with a monoclonal antibody to proliferating cell nuclear antigen (PCNA), Histopathology 19 (1991), 29-33.

[54] M.M. Zalupski et al., DNA content parameters of paraffin-embedded soft-tissue sarcomas: Optimization of retrieval technique and comparison to fresh tissue, Cytometry (1993), 327-333.

[55] R.L. Zehr, T.W. Bauer, K.E. Marks and A. Weltevreden, Ki-67 and grading of malignant fibrous histiocytoma, Cancer 66 (1990), 1984-1990.

[56] R.A. Zito, Synovial sarcoma: An Australian series of 48 cases, Pathology 16 (1984), 45-52. 


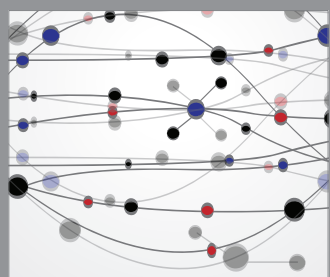

The Scientific World Journal
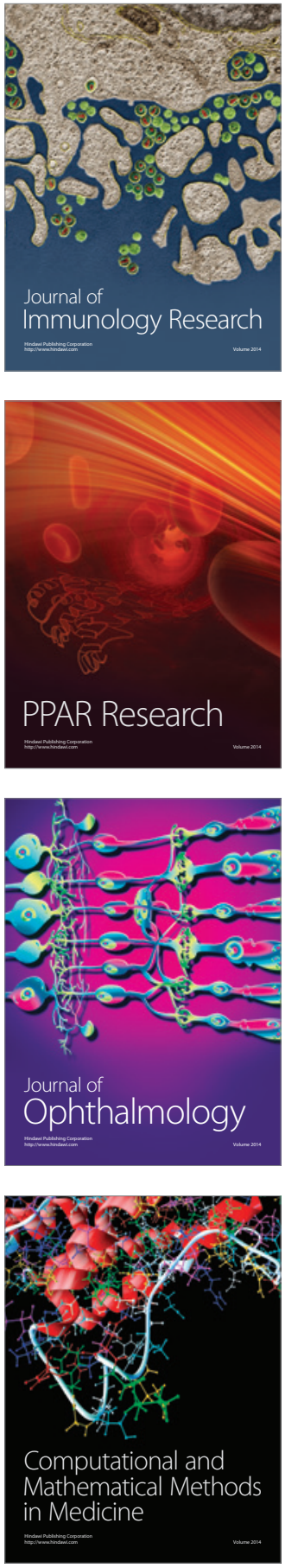

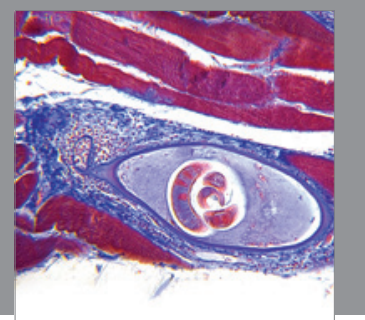

Gastroenterology

Research and Practice
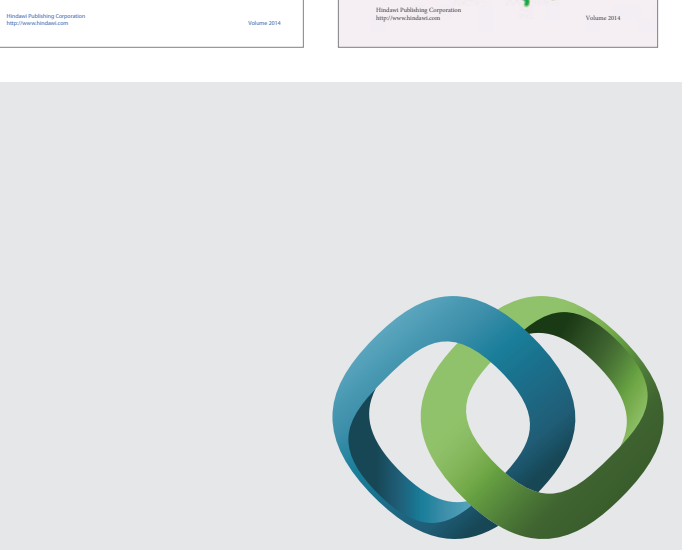

\section{Hindawi}

Submit your manuscripts at

http://www.hindawi.com
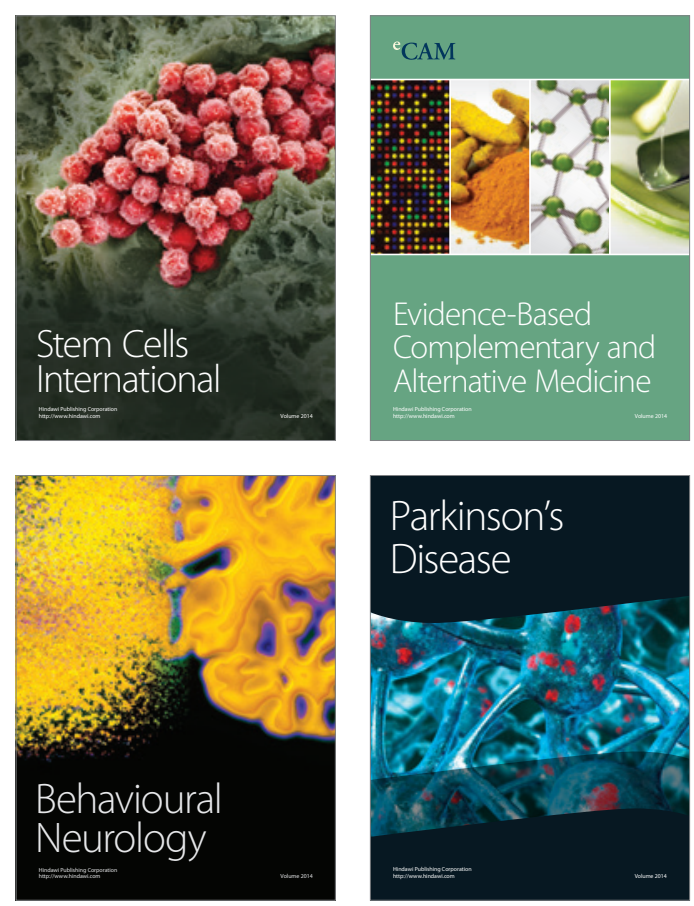

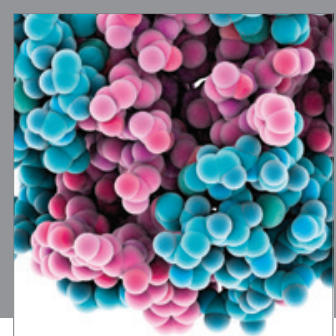

Journal of
Diabetes Research

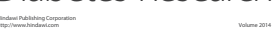

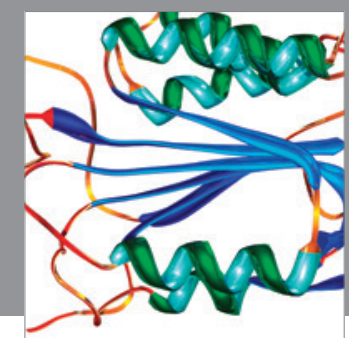

Disease Markers
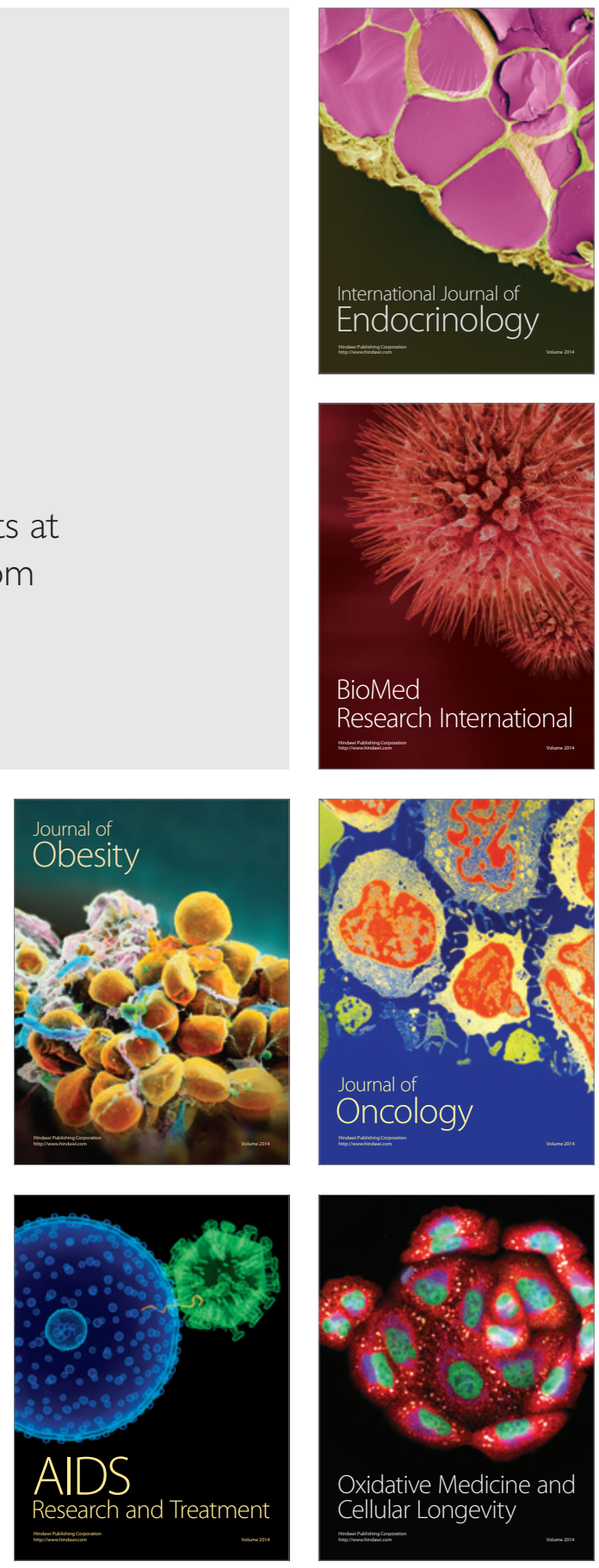